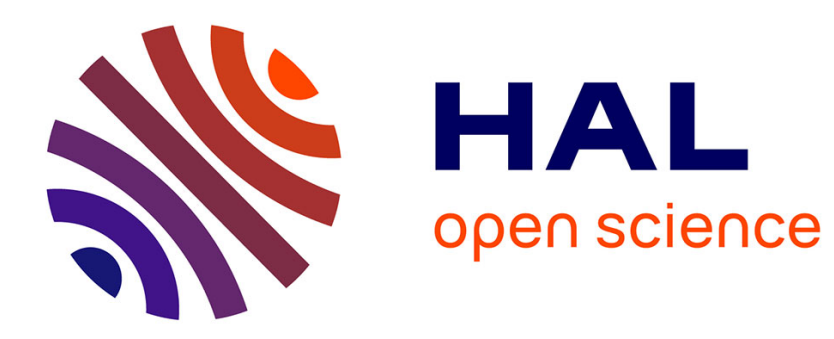

\title{
First record of Dinofelis (Felidae, Mammalia) from North Africa
}

Denis Geraads

\section{To cite this version:}

Denis Geraads. First record of Dinofelis (Felidae, Mammalia) from North Africa. Neues Jahrbuch für Geologie und Paläontologie Monatshefte, 2004, 2004 (5), pp.308-320. halshs-00004887

\section{HAL Id: halshs-00004887 https://shs.hal.science/halshs-00004887}

Submitted on 7 Oct 2005

HAL is a multi-disciplinary open access archive for the deposit and dissemination of scientific research documents, whether they are published or not. The documents may come from teaching and research institutions in France or abroad, or from public or private research centers.
L'archive ouverte pluridisciplinaire HAL, est destinée au dépôt et à la diffusion de documents scientifiques de niveau recherche, publiés ou non, émanant des établissements d'enseignement et de recherche français ou étrangers, des laboratoires publics ou privés. 


\title{
First record of Dinofelis (Felidae, Mammalia) from North Africa
}

\section{Denis GERAADS}

UPR 2147 CNRS - 44 rue de l'Amiral Mouchez, 75014 PARIS, France dgeraads@ivry.cnrs.fr

\begin{abstract}
Fragmentary dental and cranial remains from the late Pliocene of Ahl al Oughlam in Morocco are referred to Dinofelis ZDANSKY, 1924. The peculiar mastoid process, large conical upper canine and probable retention of $\mathrm{P} 2$ set this form aside from other species of the genus, which had not been reported from North Africa previously. However, in other features, it is closer to the Siwalik species D. cristata than to African ones.
\end{abstract}

\section{Zusammenfassung :}

\section{Introduction}

The site of Ahl al Oughlam in the suburbs of Casablanca, Morocco, has been dated by biochronology to about $2.5 \mathrm{Ma}$ (GERAADS \& al., 1998). It has yielded the richest fauna of the North African late Cenozoic, with about 55 species of mammals. Among them, the carnivores are extremely diverse, with 23 species (GERAADS, 1997), most of them belonging to genera of rather wide geographic range, but some showing more specific affinities with northern taxa (e.g. Ursus, Alachtherium), whereas there are also several endemic African forms (Ichneumia, a desert fox, small Mustelids of the genera Poecilictis and Prepoecilogale, and Crocuta, unknown outside Africa in Pliocene times). Therefore, the site clearly stands at a biogeographic crossroads.

A large felid from Ahl al Oughlam was briefly described (GERAADS, 1997) as Panthera aff. leo, on the basis of several dental fragments of a single individual (AaO2243). Further excavations led to the recovery of another specimen of the same species, whose features, together with re-examination of those of AaO-2243, rule out any close relation with the lion, but correspond to Dinofelis instead. 


\section{Systematic description}

Genus Dinofelis ZDANSKY, 1924

= Therailurus PIVETEAU, 1948

Type-species : Dinofelis abeli ZDANSKY, 1924

Dinofelis cf. cristata (FALCONER \& CAUTLEY, 1836)

Diagnosis (WERDELIN \& LEWIS, 2001): A Dinofelis of large size. Sagittal crest very large. Upper canine similar to Panthera in length/width relationship. P3 not reduced in length. P4 protocone not reduced. Lower canine moderately reduced. p4 relatively slender, $\mathrm{m} 1$ robust. $\mathrm{p} 3$ but not $\mathrm{p} 4$ considerably reduced in length.

It should be noted, however, that WERDELIN \& LEWIS include D. abeli ZDANSKY, 1924, the type-species, in D. cristata, and that this diagnosis partly stands for D. abeli. D. cristata s.str. differs in some features (see below).

\section{Material from Ahl al Oughlam:}

- AaO-2243 : a poorly preserved set of associated upper and lower teeth and tooth fragments, plus fragments of the premaxillae, maxillae and the right zygomatic arch. - AaO-4120 : an associated set consisting of a left mandibular fragment with $\mathrm{p} 4, \mathrm{~m} 1$ and angular process, isolated $\mathrm{p} 3$ and $\mathrm{P} 4$, some other tooth fragments, and a skull fragment with the auditory region, including the petrosal.

\section{Description:}

Skull : the zygomatic arch (AaO-2243) is deep under the orbit, and remarkably short and strongly curved behind the small post-orbital process. In these features, it matches the type specimen of Felis cristata (FALCONER \& CAUTLEY, 1836, Figs. 1-2, reproduced in Werdelin \& Lewis, 2001, Fig. 33).

The auditory region (AaO-4120) has a very peculiar morphology (Fig. 1A, B). The bulla is crushed, but was certainly small and not more salient ventrally than the paroccipital and mastoid processes. Its internal structure is not visible. The stylo-mastoid foramen was certainly small. The paroccipital process is not closely pressed against the bulla, but somewhat offset caudally, and is connected to the bulla by its sloping base. The mastoid process is farther away from the paroccipital process than in Panthera, and 
less lateral. It consists of a normal conical ventrally pointing process, but it also extends anteriorly as a flange limited dorsally by a forward extension of the supramastoid crest, stretching under the external auditory meatus. No living felid displays such a morphology. Machairodus and Homotherium are also quite different: the small paroccipital process is directed backwards, and the whole mastoid is (more or less) lengthened.

The skull fragment AaO-4120 being strongly crushed, the left petrous bone could easily be removed and studied separately. Unfortunately, neither a comparative study of the petrosal in felids, nor any description of this bone in machairodonts are available in the literature, so that only limited phyletic conclusions can be drawn from this bone.

On the whole, it is very similar to those of Felis and Panthera, but very different from those of Acinonyx (living A. jubatus and A. aicha from Ahl al Oughlam), which are strongly compressed.

Cerebellar side (Fig. 1C): the internal auditory meatus is less wide and more slit-like than in Panthera. The ridge which often tends to divide it in Panthera and still more so in Acinonyx (SALLeS, 1992, Fig. 28) is completely absent. Besides this difference, this side is close to that of Panthera in general shape and proportions. The subarcuate fossa is shallow, as often is the case in Panthera.

Tympanic side (Fig. 1D): the cochlear foramen is quite small, and smaller than the vestibular foramen. This is in sharp contrast with all living felids that $\mathrm{I}$ have seen, and also with Smilodon (Hough, 1952: 102) and nimravids (JOECKEL et al., 2002, Fig. 17). The fossa for $\mathrm{m}$. tensor tympani is very large and deep, and it seems that its limit with the epitympanic recess was indistinct, as in Panthera.

The fragment of mandibular corpus (AaO-4120; Fig. 2D, G) is not thickened medio-laterally. The missing posterior part was certainly very short, as shown by the forward extension of the masseteric fossa as far as the posterior third of $\mathrm{m} 1$, the position of the concavity of the lower border immediately behind $\mathrm{m} 1$, and the very anterior location of the caudal opening of the mandibular canal. The separate angular process is also medio-laterally thin.

Teeth : the upper incisors (AaO-2243) are poorly preserved but, from their alveoli, I1 and I2 were probably larger than in Panthera.

One of the upper canines of AaO-2243 is well-preserved, although worn along its mesial and distal crests. It bears no indication of the Panthera grooves, but is otherwise 
very similar to those of this genus, being only very slightly more compressed mediolaterally.

On the maxilla AaO-2243, behind the canine alveolus and immediately adjacent to it, there is an alveolus which is too small and too close to the canine for a P3. Among the associated set of teeth AaO-2243 are a left and a right P2 of rather large size. They are peg-like, with a main cusp and a small distal accessory one, and the whole crown is somewhat splayed out lingually. Thus, although not demonstrated because the teeth are isolated, it appears that the Dinofelis of Ahl al Oughlam had a P2, in contrast to other members of the genus.

P3 (AaO-2243) is short relative to P4. In Panthera, a P3 of the same length would correspond to a P4 of only 25-28 mm (WERDELIN \& LEWIS, 2001, Fig. 35, upper right graph), well below the length of the $\mathrm{P} 4 \mathrm{AaO}-2243$, which can be estimated from the remaining posterior lobes to be about $35 \mathrm{~mm}$. This P3 has a small antero-lingual cusp, a distal one similar to that of Panthera, and a strong posterior cingular cusp. The P4 (AaO-4120; Fig. 2C, E, F) is very slightly worn and well preserved, except for the missing protocone, which was much more reduced than in Panthera. In contrast to the latter genus, the blade is much thicker in the middle than across the anterior or posterior cusps. There is a small but distinct preparastyle, in line with the other cusps, so that the anterior lobe is almost as long as the central one, in contrast to Panthera, where it is much shorter. In lateral view, the cervix has a gentle, regular curve in the distal half of the crown, instead of the usually sharp curve above the metastyle of Panthera.

The lower canine (AaO-2243) is too poorly preserved to be described.

An isolated p3 most probably belongs to the well preserved mandible AaO-4120 (Fig. 2A, B, D, G). It is very small, with two fused roots, a vestigial anterior cuspid and a relatively thick posterior cingulum.

The p4s (present in both specimens) differ from those of Panthera by their thinner main cusp, stronger distal cingulum, and chiefly by their smaller size relative to $\mathrm{m} 1$.

The $\mathrm{m} 1$ has a protoconid that is much longer than the paraconid, and a minute vestigial talonid/metaconid.

\section{Comparisons:}

The many differences listed above demonstrate that, in contrast to my previous statement (GERAADS, 1997), no large Panthera is present at Ahl al Oughlam. 
The only other large Felids at Ahl al Oughlam are Homotherium sp. and Acinonyx aicha. The machairodont characters of AaO-2243 and AaO-4120 are much less marked than in Homotherium, but the distinction from Acinonyx is less evident. These specimens differ mainly from Acinonyx by the following features:

- overall size is larger, although the difference may be small;

- the canine is much larger;

- P3 is broader posteriorly, and its main cusp is much less dominant over the accessory ones;

- P4 has a much longer anterior lobe;

- p3 is much smaller;

- p4 is the most similar tooth in both genera, but the main cuspid in Dinofelis is relatively smaller, less lanceolate, and the posterior cingulum is thicker;

- $\mathrm{ml}$ has a longer protoconid;

- the petrous bone is completely different.

So, the distinction of AaO-4120 and AaO-2243 from Acinonyx is not in question. Finally, comparison with Dinofelis, a genus recently revised by WERDELIN \& LEWIS (2001), shows that these specimens display the characteristic features of this genus. In particular, detailed comparison with the well-preserved dentition of the skull Omo-28-67-1075 from the Shungura Formation, referred to the new species $D$. petteri by these authors, reveals the almost identical morphology of the P4: small protocone, long first lobe, blade tapering mesially and distally, conspicuous preparastyle, cutting edge of the metastyle parallel to the long axis of the tooth in lateral view. Thus, there is no doubt that these fossils belong to Dinofelis.

According to WERDELIN \& LEWIS (2001), this genus contains the following African species:

* D. barlowi (Broom, 1937), from the Pliocene of South Africa (Sterkfontein, Swartkrans, Bolt's Farm);

* D. darti (TOERIEN, 1955), from the Pliocene of South Africa (Makapansgat);

* D. petteri WeRdelin \& LeWIS, 2001, from the Pliocene of East Africa;

* D. aronoki WERDELIN \& LEWIS, 2001, from the late Pliocene and earliest Pleistocene of East Africa;

* D. piveteaui (EWER, 1955), from the Pleistocene of East and South Africa;

* Dinofelis sp. from the Mio-Pliocene of Lothagam (WERDELIN \& LEWIS, 2001; WERDELIN, 2003); 
* Dinofelis sp. from the early Pliocene of Langebaanweg (HENDEY, 1974);

* Dinofelis sp from the early Pleistocene of East Africa (Olduvai).

The Ahl al Oughlam Dinofelis differs from D. barlowi by:

- the anterior expansion of the mastoid shelf, which is only incipient in the latter

(COOKE, 1991, Fig. 2; photos of a cast of this specimen were kindly made available to me by G. PetTer);

- its shorter P3.

It differs from $D$. darti by:

- the smaller main cuspid of $\mathrm{p} 4$;

- its stouter $\mathrm{m} 1$.

It differs from $D$. petteri by:

- its shorter P3 and p3;

- probably more reduced protocone of $\mathrm{P} 4$;

- longer $\mathrm{m} 1$ relative to $\mathrm{p} 4$.

All these features are more derived, but the mandibular corpus AaO-4120 is otherwise rather similar to that of Kanapoi (WERDELIN \& LEWIS, 2001, Fig. 6).

It differs from $D$. aronoki by:

- its less reduced $\mathrm{p} 3$ and $\mathrm{p} 4$;

- its thicker $\mathrm{m} 1$.

Furthermore, the Ahl al Oughlam Dinofelis differs from all these species by - the presence of $\mathrm{P} 2$;

- the large size of the canine, which is also only slightly compressed.

It cannot be ruled out that the former character, which is obviously primitive, might be an individual variation, since it is known in only one specimen. However, the large size of the $\mathrm{P} 2$ in AaO-2243 seems to preclude this.

The large size of the canine (Fig. 3) and its slight compression, which were the basis for the previous referral of this specimen to Panthera, are the most noticeable features of the Ahl al Oughlam Dinofelis, and they set it apart from all African species.

A single, isolated tooth from North Africa might be co-specific. It is the P4 from the Middle (?) Pliocene of Aïn Brimba in Tunisia, referred by Arambourg (1979; pl.59, fig.8) to "Machairodontinae incertae sedis" (Muséum National d'Histoire Naturelle, Paris, $\left.\mathrm{N}^{\circ} 1958-14-163\right)$. By its size (32.8 x 14.2) and morphology, it is very similar to $\mathrm{AaO}-4120$, although the preparastyle is smaller and more lateral, and the protocone probably slightly larger. I tentatively refer it to Dinofelis? sp. 
The Dinofelis from Ahl al Oughlam should also be compared with the Eurasian forms, which are (HEMMER, 1965; WERDELIN \& LEWIS, 2001):

*D. diastemata (ASTRE, 1929), from the Pliocene of southern France;

* Some specimens from Europe and the Black Sea region, described without specific names;

* D. abeli ZDANSKY, 1924, the type-species, from the Pliocene of China;

* D. cristata (FAlconer \& CAUTLey, 1836), from the Pinjor zone of the Siwaliks, considered by WERDELIN \& LEWIS (2001) to be a synonym of the former.

D. diastemata is primitive in having a strong $\mathrm{P} 4$ protocone, and it further differs from AaO-4120 by the lack of the mastoid anterior shelf (PIVETEAU, 1948).

The Dinofelis from Balaruc II (BEAUMONT, 1983) is roughly contemporaneous with the Moroccan one, and geographically close, but very different by its large p3, and very long $\mathrm{p} 4$ with weak posterior cingulum.

The skull fragments from the Pleistocene of Etulia in Moldavia (AVERIANOV \& BARYSHNIKOV, 1999) have a relatively long and slender zygomatic arch, a P4 with a very small preparastyle, large protocone, large M1, large bulla, no anterior mastoid shelf, and a paroccipital process which is not hook-shaped. So, they are rather different from the Moroccan specimens, and rather more primitive, in spite of their late age.

The earlier skull from Zemo Melaani in Georgia (WERDELIN \& LEWIS, 2001, Fig. 32) has more similar P3-M1, but the canines are more compressed, with a straight if not convex posterior edge.

The genus has also been reported (as Therailurus) from the Pliocene of Kvabebi in the Caucasus. The only specimen is a mandible fragment with $\mathrm{p} 4$ and $\mathrm{m} 1$ whose available measurements (VEKUA, 1972) are quite similar to those of Ahl al Oughlam.

The eastern Asiatic species differ from the African ones in their less compressed upper canines (WERDELIN \& LEWIS, 2001, Fig. 35, upper left graph), a feature that they share with the Moroccan form but, in common with African forms and in contrast to the Moroccan one, this tooth is relatively small. The zygomatic arch is strongly curved in D. cristata (WeRDELIN \& LEWIS, 2001, Fig. 33, 34), as at Ahl al Oughlam, whereas it looks straight in D. abeli (ZDANSKY, 1924: 137), but this is probably due to post-mortem deformation of the Chinese skull (L.WERDELIN, pers. comm.). D. abeli also has very long P3 and p4, (Werdelin \& LEWIS, Fig.35, upper right graph; Fig. 37, middle graph), in contrast to the specimens from Ahl al Oughlam. The Siwalik species has a slightly 
shorter P3, and perhaps shorter p4, if specimen BM 48437 discussed by HEMMER (1973: 163) does belong to this species.

\section{Conclusion}

The diagnoses of African species of Dinofelis by WERDELIN \& LEWIS (2001) mostly rest upon tooth proportions, although examinations of their graphs show that clustering of specimens into species is less straightforward than one might expect. Some of the tooth proportions of the Moroccan form (L/W of p4, Lp3/Lm1, etc.) are close to D. aronoki, D. darti and $D$. petteri, but it is not possible to refer it to any of these. It looks closer to $D$. cristata from the Siwaliks, whose synonymy with $D$. abeli from China, rests upon light evidence. This would suggest some latitudinal differentiation, which is supported by the sharp differences displayed by the specimens from the northern side of the Mediterranean (especially Etulia and Balaruc), but remains to be further substantiated.

\section{Acknowledgments}

I am grateful to J. HASSAR BENSLIMANE, head of the "Institut National des Sciences de l'Archéologie et du Patrimoine", and to F.-Z. SBIHI-AlAOUI, head of the "Programme Casablanca", for having entrusted me with the study of the Ahl al Oughlam fossils. Thanks also to M. MORLO and L. WERDELIN, whose comments greatly improved the text, to G. PETTER, who provided photos of several Dinofelis fossils, to Mrs MAMITU YILMA for giving me facilities to work in the National Museum, Addis Ababa, and to F. RenOult, for doing the same in the Muséum National d'Histoire Naturelle, Paris. Autorisation de publier $\mathrm{n}^{\circ} 000$

\section{References}

ArambourG, C. (1979): Vertébrés villafranchiens d'Afrique du Nord (Artiodactyles, Carnivores, Primates, Reptiles, Oiseaux). Paris (Fondation Singer-Polignac), 1141.

Astre, G. (1929): Sur un Félin à particularités ursoïdes des limons pliocènes du Roussillon. - Bull. Soc. géol. Fr., 29: 199-204.

Averianov, O.A., \& Baryshnikov, G.F. (1999): Dinofelis sp (Carnivora, Felidae) from the Late Pliocene locality Etulia in Moldavia. - N. Jb. Geol. Paläont. Mh., 1999 (9): 531-540. 
Beaumont, G. de, (1983): Une mandibule de Dinofelis (Mammifères, Carnivore, Félidé) du Villafranchien inférieur de Balaruc II, Hérault, France. - Arch. Sc. Genève, 36 (3): 469-478.

Cooke, H.B.S. (1991): Dinofelis barlowi (Mammalia, Carnivora, Felidae) cranial material from Bolt's Farm, collected by the University of California African expedition. Palaeont. Afr., 28: 9-21.

EWER, R.F. (1955): The fossil carnivores of the Transvaal caves: Machairodontinae. Proc. Zool. Soc. London, 125: 587-615.

Falconer, H. \& CAutley, P.T. (1836): Note on the Felis cristata, a new fossil tiger from the Sivalik Hills. - Asiatic Res., 19: 135-142.

GerAads, D. (1997): Carnivores du Pliocène terminal de Ahl al Oughlam (Casablanca, Maroc). - Géobios, 30 (1): 127-164.

GeraAds, D., Amani, F., Raynal, J.-P. \& SBihi-Alaoui, F.-Z. (1998): La faune de Mammifères du Pliocène terminal d'Ahl al Oughlam, Casablanca, Maroc. - C. R. Acad. Sci., Sci. Terre Plan., Paris, 326: 671-676.

HEMmer, H. (1965): Zur Nomenklatur und Verbreitung des Genus Dinofelis Zdansky, 1924 (Therailurus PIVETEAU, 1948). - Palaeont. Afr., 9: 75-89.

HEMmER, H. (1973): Neue Befunde zur Verbreitung und Evolution der pliozänpleistozänen Gattung Dinofelis (Mammalia, Carnivora, Felidae). - N. Jb. Geol. Paläont. Mh, 1973 (3): 157-169.

Hendey, Q.B. (1974): The late Cenozoic Carnivora of the South-Western Cape province. - Ann. S. Afr. Mus., 63: 1-369.

Hough, J.R. (1953): Auditory region in North American fossil Felidae: its significance in phylogeny. - US geol. Surv. Prof. paper, 243 G: 95-115.

Joeckel, R.M., Peigné, S., Hunt, R.M.JR, \& SkOlnick, R.I. (2002): The auditory region and nasal cavity of Oligocene Nimravidae (Mammalia, Carnivora). J.Vert.Paleont., 22 (4): 830-847.

Piveteau, J. (1948): Un Félidé du Pliocène du Roussillon. - Ann. Paléont., 34: 99-124.

SALLES, L.O. (1992): Felid phylogenetics: extant taxa and skull morphology (Felidae, Aeluroidea). - Amer. Mus. Novit., 3047: 1-67.

ToERIEN, M.J. (1955): A sabre-tooth cat from the Makapansgat valley. - Palaeont. Afr., 3: $43-46$.

VeKuA, A.K. (1972): Kvabebskaia fauna Akchagylskih Pozvonochnyh. Nauka, Moskva, $1-350$. 
Werdelin, L. (2003): Mio-Pliocene Carnivora from Lothagam, Kenya. P. 261-328, In:

LEAKEY, M.G. \& HARRIS, J.M. (Eds): Lothagam: the dawn of Humanity in Eastern Africa. New York (Columbia University Press).

Werdelin, L. \& LEWIS, M.E. (2001): A revision of the genus Dinofelis (Mammalia, Felidae). - Zool. J. Linn. Soc., 132: 147-258.

ZdANSKY, O. (1924): Jungtertiäre Carnivoren Chinas. - Palaeont. Sin., C; 2 (1): 1-149. 
TABLE 1 Dental measurements of the Ahl al Oughlam Dinofelis

Upper teeth

\begin{tabular}{ccccccccccc}
\multicolumn{2}{c}{ C/ } & \multicolumn{2}{c}{ P2 } & \multicolumn{2}{c}{ P3 } & \multicolumn{2}{c}{ P4 } & \multicolumn{2}{c}{ M1 } \\
L & W & L & W & L & W & L & W & L & W \\
& & & & & & 31.8 & $14 ?$ & 5.5 & 8.9 \\
25.3 & 16.5 & 11.7 & 8.4 & 18.1 & 10.6 & $35 ?$ & - & &
\end{tabular}

Lower teeth

\begin{tabular}{ccccccc} 
& \multicolumn{2}{c}{ p3 } & \multicolumn{2}{c}{ p4 } & \multicolumn{2}{c}{$\mathrm{m} 1$} \\
& $\mathrm{~L}$ & $\mathrm{~W}$ & $\mathrm{~L}$ & $\mathrm{~W}$ & $\mathrm{~L}$ & $\mathrm{~W}$ \\
$\mathrm{AaO}-4120$ & 11.4 & 6.9 & 20.6 & 9.7 & 24.8 & 12.7 \\
$\mathrm{AaO}-2243$ & - & - & 21.5 & $11 ?$ & $27 ?$ & -
\end{tabular}

Figure captions:

Fig.1. Dinofelis sp., AaO-4120, Ahl al Oughlam. Right auditory region. A: lateral view; B: basal view. Stereo pairs. C-D: left petrosal in C, cerebellar and D, tympanic views. The rostral part is towards the top of the page. Scale $=6 \mathrm{~cm}$ for Figs A-B, $2 \mathrm{~cm}$ for Figs. C-D.

Fig.2. Dinofelis sp., AaO-4120, Ahl al Oughlam. A: mandible with p4-m1; B: p3; C: P4. A-B-C: occlusal views, stereo pairs. D: same specimens as A-B, lateral view; E: same specimen as C, lateral view; F: same specimen as C, E, lingual view; G: same specimens as A, B, D, lingual view. Scale $=2 \mathrm{~cm}$.

Fig.3. Scatterplot of upper P3 vs. upper C length (mesio-distal) in Dinofelis. AaO-2243 from Ahl al Oughlam has a relatively very long canine. Other measurements from Werdelin \& Lewis, 2001, Table 1. 